\section{(1) \\ CrossMark}

\title{
Systematic review and meta-analysis of residential radon and lung cancer in never-smokers
}

\author{
Elvin S. Cheng $\mathbb{1}^{1,2}$, Sam Egger ${ }^{1}$, Suzanne Hughes ${ }^{1,2}$, Marianne Weber ${ }^{1,2}$, \\ Julia Steinberg (101,2, Bayzidur Rahman ${ }^{3}$, Heather Worth ${ }^{3}$, \\ Alberto Ruano-Ravina ${ }^{4,5,6}$, Patrick Rawstorne ${ }^{3,7}$ and Xue Qin Yu ${ }^{1,2,7}$
}

Affiliations: ${ }^{1}$ Cancer Research Division, Cancer Council NSW, Sydney, Australia. ${ }^{2}$ School of Public Health, Faculty of Medicine and Health, University of Sydney, Sydney, Australia. ${ }^{3}$ School of Public Health and Community Medicine, University of New South Wales, Sydney, Australia. ${ }^{4}$ Dept of Preventive Medicine and Public Health, University of Santiago de Compostela, Santiago de Compostela, Spain. ${ }^{5}$ Consortium for Biomedical Research in Epidemiology and Public Health ICIBERESP, Consorcio de Investigación Biomédica en Red de Epidemiología y Salud Pública), Madrid, Spain. ${ }^{6}$ Health Research Institute of Santiago de Compostela (IDIS), Santiago de Compostela, Spain. ${ }^{7}$ Equal contribution as last author.

Correspondence: Elvin S. Cheng, Cancer Research Division, Cancer Council NSW, 153 Dowling Street, Woolloomooloo NSW 2011, Australia. E-mail: elvin.chenglanswcc.org.au

@ERSpublications

Globally, radon is the leading cause of lung cancer in never-smokers. Yet its quantified link with lung cancer risk among never-smokers is not known. This study computes the risk estimate of lung cancer from residential radon exposure among never-smokers. https://bit.ly/32frCbq

Cite this article as: Cheng ES, Egger S, Hughes S, et al. Systematic review and meta-analysis of residential radon and lung cancer in never-smokers. Eur Respir Rev 2021; 30: 200230 [https://doi.org/10.1183/ 16000617.0230-2020].

\section{ABSTRACT}

Background: Globally, radon is the leading risk factor for lung cancer in never-smokers (LCINS). In this study, we systematically reviewed and meta-analysed the evidence of the risk of LCINS associated with residential radon exposure.

Methods: Medline and Embase databases were searched using predefined inclusion and exclusion criteria to identify relevant studies published from 1 January 1990 to 5 March 2020 focused on never-smokers. We identified four pooled collaborative studies (incorporating data from 24 case-control studies), one casecontrol study and one cohort study for systematic review. Meta-analysis was performed on the results of the four pooled studies due to different measures of effect and outcome reported in the cohort study and insufficient information reported for the case-control study. In a post hoc analysis, the corresponding risk for ever-smokers was also examined.

Results: Risk estimates of lung cancer from residential radon exposure were pooled in the meta-analysis for 2341 never-smoker cases, 8967 never-smoker controls, 9937 ever-smoker cases and 12463 ever-smoker controls. Adjusted excess relative risks (aERRs) per $100 \mathrm{~Bq} \cdot \mathrm{m}^{-3}$ of radon level were 0.15 (95\% CI $0.06-$ 0.25 ) for never-smokers and 0.09 (95\% CI 0.03-0.16) for ever-smokers, and the difference between them was statistically insignificant $(\mathrm{p}=0.32)$. The aERR per $100 \mathrm{~Bq} \cdot \mathrm{m}^{-3}$ was higher for men $(0.46$; $95 \%$ CI $0.15-$ $0.76)$ than for women $(0.09 ; 95 \% \mathrm{CI}-0.02-0.20)$ among never-smokers $(\mathrm{p}=0.027)$.

Conclusion: This study provided quantified risk estimates for lung cancer from residential radon exposure among both never-smokers and ever-smokers. Among never-smokers in radon-prone areas, men were at higher risk of lung cancer than women.

\section{This article has supplementary material available from err.ersjournals.com}

Provenance: Submitted article, peer reviewed.

Received: 16 July 2020 | Accepted: 28 Oct 2020

Copyright OERS 2021 This article is open access and distributed under the terms of the Creative Commons Attribution Non-Commercial Licence 4.0. 


\section{Introduction}

Lung cancer has long been the most commonly diagnosed cancer and the leading cause of cancer-related deaths globally [1]. Although tobacco smoking is responsible for the great majority of lung cancers, 15 to $25 \%$ of cases occur in lifelong never-smokers [1-3] ("never-smokers" are defined as individuals who have smoked $<100$ cigarettes in their lifetime according to the International Consortium for Health Outcomes Measurement [4]). Lung cancer in never-smokers (LCINS) has been recognised as a distinct disease entity from that in ever-smokers [2, 3, 5-8], and its significant impact has been indicated by being ranked in 2000 as the seventh most common cause of cancer death worldwide $[2,9,10]$. Numerous risk factors have been suggested for the development of LCINS, including exposure to radon, asbestos, environmental tobacco smoke, air pollution, heavy metals, lifestyle factors, female hormonal factors, human papillomavirus infection and inherited genetic susceptibility [7, 11-13]. Radon was classified as a Group 1 carcinogen for lung cancer by the International Agency for Research on Cancer (IARC) [14]. Also, based on substantial epidemiological evidence showing a strong and consistent dose-response relationship of increased lung cancer risk with high-level occupational radon exposure amongst underground miners [15-17], radon exposure has been identified as the second strongest risk factor for lung cancer only after smoking, and is the leading risk factor for LCINS worldwide $[18,19]$. However, the risk estimate of lung cancer from exposure to residential radon in the general population remains unclear.

Radon is a naturally occurring radioactive noble gas present throughout the earth's crust. As a chemically inert gas, it can readily diffuse through rocks and soil into any air space and accumulate in enclosed areas or unventilated environments [20]. One of its isotopes closely linked to lung cancer, Radon-222, is a transient product of the uranium-238 decay chain [21], and is the greatest source of radiation for humans [22]. As Radon has a half-life of 3.82 days, when it is inhaled, most of the Radon is exhaled before it undergoes substantial decay. However, the decay products or radon progenies adhere to the airways of the lungs, where they are thought to continue to emit radioactive alpha particles to induce carcinogenesis and potentially culminate in lung cancer. The radiation received by humans via radon progeny is higher than that via radon-222 itself, but it is directly proportional to radon-222 exposure [23].

In extrapolating the risk of occupational radon exposure among miners to residential radon exposure in the general population, there are several limitations: 1) the health effects of residential radon are more difficult to evaluate due to the much lower radon concentration in residential environments than that in mines (about 100 times lower); 2) the air composition in mines contains some other carcinogens (such as arsenic and various dusts) that are not commonly found in residential dwellings; and 3) the characteristics of the exposed populations are different, as miners are usually young men, while both sexes of all ages can be exposed to residential radon [24].

Since 1990, numerous case-control studies have been conducted in both high- and low-radon areas in Europe, North America and China to assess the excess risks of lung cancer attributable to residential radon exposure [25-45]. Due to the relatively small sample sizes of these case-control studies, large pooled collaborative studies [46-52] and several meta-analyses [53-58] were conducted, aiming to acquire similar statistical power as the epidemiologic studies of underground miners [59], as well as to provide a comparison of the pooled risk estimates with extrapolations from the miner-based risk models [49]. While the pooled collaborative studies have shown significant positive associations between residential radon exposure and lung cancer risk to varying degrees, all but one pooled study [52] assessed this association in populations of both ever-smokers and never-smokers. To establish a clear link between radon and LCINS, it is important to focus on studies with exclusive or subgroup analyses of never-smokers, rather than extrapolating excess risks among smokers to LCINS given the residual confounding by smoking and other factors. We therefore undertook a systematic review and meta-analysis to examine and quantify the association between residential radon exposure and lung cancer risk among never-smokers.

\section{Methods}

\section{Protocol and registration}

The conduct and reporting of this systematic review and meta-analysis adhered to the Preferred Reporting Items for Systematic Reviews and Meta-Analyses (PRISMA) statement checklist [60] (supplementary table 1), and has been registered at PROSPERO with identifier number CRD42020154551.

\section{Databases and search methods}

Medline and Embase databases were initially searched for eligible articles published from 1990 onwards by combining text terms and database specific subject headings for "lung cancer" and "radon" in November 2017 (supplementary table 2). Two more searches were then run in October 2019 and March 2020 and the search results were updated to 5 March 2020 (supplementary table 3). 


\begin{tabular}{|c|c|c|}
\hline Domain & Inclusion criteria & Exclusion criteria \\
\hline Study type/design & $\begin{array}{l}\text { Pooled data analysis of cohort or case- } \\
\text { control studies } \\
\text { Meta-analysis of cohort or case-control } \\
\text { studies } \\
\text { Systematic review of cohort or case-control } \\
\text { studies } \\
\text { Cohort study } \\
\text { Case-control study }\end{array}$ & Ecological study case series \\
\hline Study population & Never-smokers $(<100$ cigarettes in lifetime) & \\
\hline $\begin{array}{l}\text { Exposure } \\
\text { Comparator }\end{array}$ & $\begin{array}{l}\text { Indoor or residential radon exposure } \\
\text { No or lower radon exposure }\end{array}$ & Mining radon exposure \\
\hline $\begin{array}{l}\text { Outcome } \\
\text { Time of publication }\end{array}$ & $\begin{array}{l}\text { Lung cancer diagnosis or death } \\
\text { Published from } 1 \text { January } 1990 \text { to } 5 \text { March } \\
2020\end{array}$ & Published before 1990 \\
\hline Publication type & Full-text published article & $\begin{array}{l}\text { Editorials, conference proceedings, } \\
\text { abstracts, posters, narrative } \\
\text { reviews, commentaries, grey } \\
\text { literature }\end{array}$ \\
\hline Language & English & Language other than English \\
\hline
\end{tabular}

\section{Study eligibility criteria}

The PICO (population, intervention, comparator and outcome) framework was adopted in our search strategy, and studies were selected based on pre-defined inclusion and exclusion criteria which are summarised in table 1. The population was never-smokers. The exposure of interest was indoor or residential radon exposure, and the comparator was no or low radon exposure. The outcome was lung cancer diagnosis or death. Published articles were included if they reported full or subgroup analyses of the association between residential radon exposure and LCINS. A more detailed account of the application of these criteria is provided in the Technical Appendix in the Supplementary material.

\section{Study selection and data extraction}

Titles and abstracts of citations identified by the database searches were examined by one reviewer (E. Cheng) and clearly irrelevant articles were excluded. The full texts of the potentially relevant articles were retrieved and evaluated for inclusion by one reviewer (E. Cheng); where uncertainties arose a second reviewer (S. Hughes) was consulted. The reasons for excluding retrieved articles were documented. Relevant pre-specified study characteristics relating to country/region of study, study design and population, sex and population source, number of cases and controls, study period, exposure measurement and results were extracted from the included articles by one reviewer (E. Cheng) and cross-checked by a second reviewer (S. Hughes). Differences were resolved by discussion and/or advice from a third reviewer (X.Q. Yu).

\section{Assessment of study quality}

The quality of the included studies was assessed independently by two reviewers (E. Cheng and X.Q. Yu). The ROBIS tool [61] was used to assess the risk of bias (ROB) for the pooled collaborative studies, and items were scored as low, high or unknown/unclear concern for ROB. Adaptions of the Newcastle-Ottawa Scale developed to assess the ROB for epidemiological cohort studies and case-control studies [62] were used to assess the cohort and case-control studies, and items were scored as low, moderate or high ROB.

\section{Post hoc analysis for ever-smokers}

As a post hoc analysis using relevant data from the included studies, we also conducted a meta-analysis to examine and quantify the association between residential radon exposure and lung cancer risk among ever-smokers in order to examine the role of personal smoking as an effect modifier.

\section{Data extraction and management}

For the meta-analysis, two reviewers (E. Cheng and S. Egger) extracted effect estimates and standard errors for never-smokers and categories of ever-smokers (i.e. ever-smoker; or current-smoker and ex-smoker; or 
ever-smoker with lifetime exposure divided into tertiles) in each study with discrepancies resolved by consensus or adjudication from another reviewer (X.Q. Yu).

Preferably, estimates of the adjusted excess relative risk (aERR) per $100 \mathrm{~Bq} \cdot \mathrm{m}^{-3}$ were extracted if available. The common confounders included in the adjustment were age, sex, education, occupations with high risk of lung cancer and exposure to environmental tobacco smoke. Stata 14 was used for statistical analyses. A full account of data extraction and management is provided in the Technical Appendix in the supplementary material.

\section{Data synthesis}

To pool estimates of aERRs per $100 \mathrm{~Bq} \cdot \mathrm{m}^{-3}$ for never-smokers and ever-smokers, we used methods outlined by LiTTLE et al. [63]. Briefly, the fixed-effect inverse variance weighted pooled aERRs for never-smokers and ever-smokers were calculated as:

$$
a E R R_{t o t}=\frac{\sum_{i=1}^{N} \frac{a E R R i}{s d(a E R R i)^{2}}}{\sum_{i=1}^{N} \frac{1}{\operatorname{sd}(a E R R i)^{2}}}
$$

where $a E R R \mathrm{i}$ is the reported aERR estimate for the ith individual or collaborative study, and $S D(a E R R i)$ is the standard deviation of the estimate. The standard pooled SD was calculated as:

$$
S D\left(a E R R_{t o t}\right)=\frac{1}{\sqrt{\sum_{i=1}^{N} \frac{1}{s d(a E R R i)^{2}}}}
$$

A random-effects approach was not used because of the necessity to include pooled estimates from collaborative studies in our meta-analysis. Also, a measure of heterogeneity across the component studies in the pooled analysis, which is needed for an analysis using random effects, was not reported and could not be assessed.

We also used the above method to pool estimates of aERRs per $100 \mathrm{~Bq} \cdot \mathrm{m}^{-3}$ for never-smokers stratified by sex based on the results of the two collaborative studies that provided this information $[51,52]$.

\section{Sensitivity analysis}

We performed sensitivity analyses in which the component effect estimates were pooled on the $\log (\mathrm{RR})$ scale (instead of the ERR scale) using the standard generic inverse variance method. The rationale for the statistical analyses is provided in the Technical Appendix in the supplementary material.

\section{Results \\ Search results}

A flowchart of the search process and inclusion/exclusion results is shown in figure 1. We identified 2453 articles through an initial literature search of which nine met the selection criteria and were included in the systematic review. Of these nine articles, seven reported the findings from four pooled collaborative analyses [46-52] of case-control data from a total of 24 studies [25-40, 42-45, 64-66] (one of them, TомAseк [26], was a cohort study re-analysed as a nested case-control study in a pooled collaborative analysis), one was a cohort study [67] and one was a case-control study [68] that had not been included in any of the pooled analyses (table 2). Only the cohort study [67] examined associations with death from lung cancer, all the remaining studies examined associations with a diagnosis of lung cancer.

For diagnosis of lung cancer, a meta-analysis of the four pooled collaborative analyses was undertaken. Results of the Spanish pooled studies reported by LoRENZO-GonZALEz et al. [52] were updated for our analysis with unpublished data obtained from the lead investigators and the results reported in BARRos-Dios et al. [33] were excluded as they had already contributed to the pooled study of DarBY et al. [48]. The meta-analysis did not include the cohort study [67] and the individual case-control study [68] because: 1) the cohort study reported measures of effect (aIRR and aHR) that are incompatible with the aERRs and aRRs used in the pooled case-control analyses; and 2) the case-control study did not report standard errors or confidence intervals for the relevant effect estimates.

Overall, four collaborative studies (containing pooled estimates from 24 individual studies) contributed to the meta-analysis for never-smokers. Of these four studies, three pooled collaborative studies (reporting pooled estimates from 21 individual studies) and one individual study (BARros-Dios et al. [66]) from the fourth pooled study contributed to the meta-analysis for ever-smokers. Data were pooled for 2341 


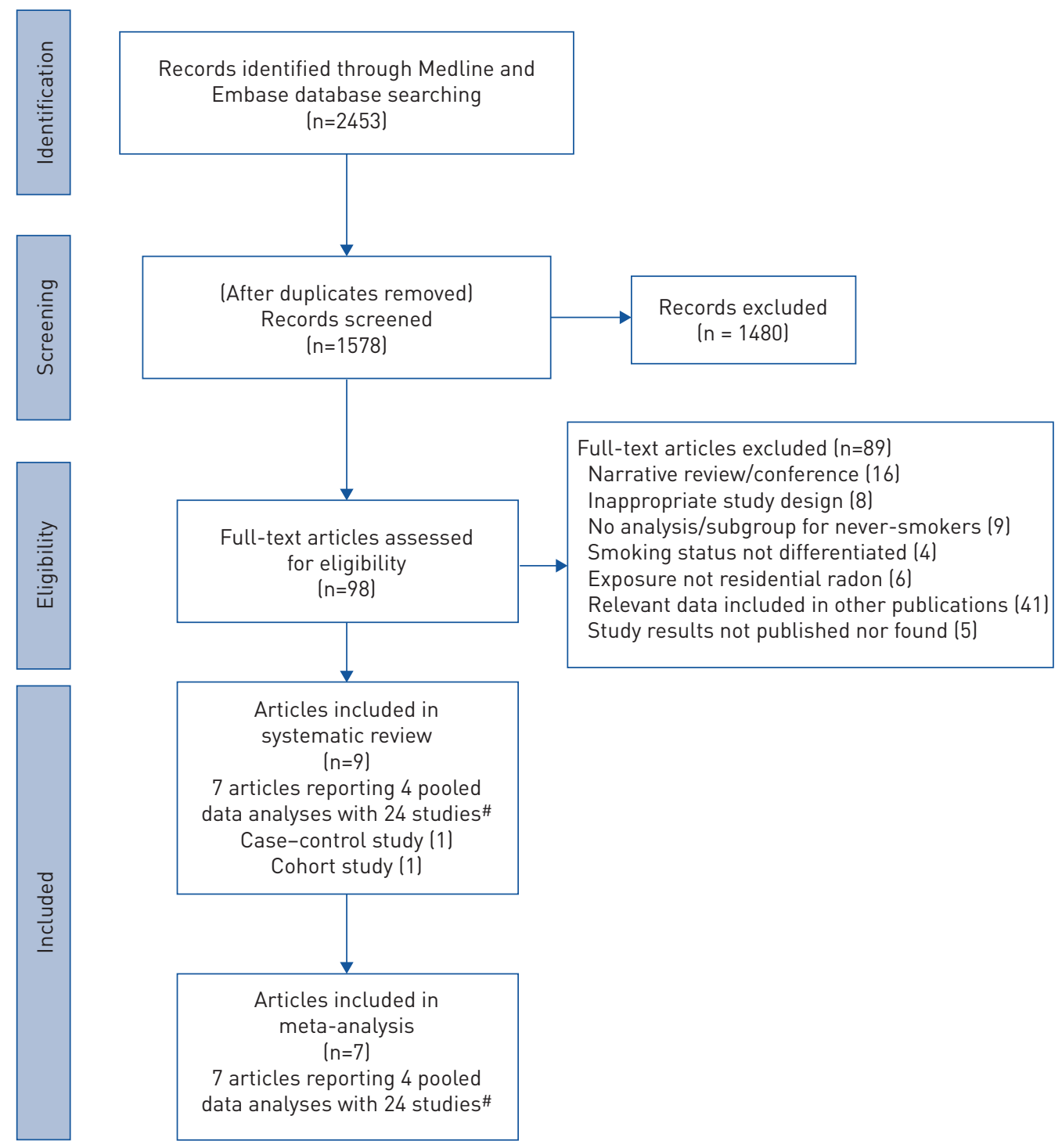

FIGURE 1 Flowchart of the search process and results for studies looking at radon and lung cancer in never-smokers. \#: these 24 studies are unique individual studies included in the four pooled data analyses. Accordingly, BARROS-Dios et al. [33], which appears in two of the four pooled data analyses, is only counted once.

never-smoker cases, 8967 never-smoker controls, 9937 ever-smoker cases and 12463 ever-smoker controls (in total, 12278 cases and 21430 controls).

Of the 24 individual studies included in the never-smoker meta-analysis, 15 (from two pooled studies [51, 52]) were eligible for inclusion in the sex-stratified meta-analyses. In this analysis, data were pooled separately for 990 female never-smoker cases and 2898 female never-smoker controls, and 370 male never-smoker cases and 3176 male never-smoker controls (in total, 1360 never-smoker cases and 6074 never-smoker controls, representing $58 \%$ and $68 \%$ of the never-smoker cases and controls included in the overall never-smoker pooled estimate, respectively).

\section{Quality of included studies}

The ROB for each of the included studies is shown in supplementary table 4. Overall, the pooled collaborative studies were rated as having a low ROB, the cohort study [67] was rated as having a moderate ROB and the case-control study [68] was rated as having a high ROB.

\section{Results from the meta-analysis}

To quantify the association between residential radon exposure and lung cancer risk, we demonstrated that the aERRs per $100 \mathrm{~Bq} \cdot \mathrm{m}^{-3}$ were 0.15 (95\% CI 0.06-0.25) for never-smokers, 0.09 (95\% CI 0.03-0.16) for 


\begin{tabular}{|c|c|c|c|c|c|c|c|c|c|c|c|}
\hline \multirow{2}{*}{$\begin{array}{l}\text { First author } \\
\text { [ref.] }\end{array}$} & \multirow[t]{2}{*}{ Country/region } & \multirow[t]{2}{*}{ Study period } & \multirow[t]{2}{*}{ Study design } & \multirow{2}{*}{$\begin{array}{l}\text { Radon detection } \\
\text { technique }\end{array}$} & \multirow[t]{2}{*}{ Sex } & \multirow{2}{*}{$\begin{array}{l}\text { Population } \\
\text { source }\end{array}$} & \multirow{2}{*}{$\begin{array}{c}\text { Outcome: LC } \\
\text { diagnosis/ } \\
\text { death }\end{array}$} & \multicolumn{2}{|c|}{ Never-smokers } & \multicolumn{2}{|c|}{ Ever-smokers } \\
\hline & & & & & & & & Cases & Controls & Cases & Controls \\
\hline $\begin{array}{l}\operatorname{DARBY}_{\text {AR8 }}[48]^{\# \uparrow} \\
\operatorname{DARBY}[51]^{\# \uparrow}\end{array}$ & Europe & $1960-99$ & Pooled study & & $M / F$ & General+hospital & Diagnosis & 884 & 5418 & 6040 & 8252 \\
\hline Oberaigner[25] & Austria & $1970-92$ & $\mathrm{C}-\mathrm{C}$ & & $\mathrm{M} / \mathrm{F}$ & General & Diagnosis & 22 & 41 & 159 & 127 \\
\hline TOMASEK[26] & Czechia & $1960-99$ & Cohort & Kodak LR115 & $\mathrm{M} / \mathrm{F}$ & General & Death & 28 & 295 & 143 & 417 \\
\hline Auvinen [27] & Finland & $1986-92$ & $\mathrm{C}-\mathrm{C}$ & Alpha track & $\mathrm{M} / \mathrm{F}$ & General & Diagnosis & 44 & 229 & 772 & 752 \\
\hline RuosteenOJa[28] & Finland & $1979-85$ & $C-C$ & $\begin{array}{c}\text { Radon } \\
\text { dosimeter }\end{array}$ & $M$ & General & Diagnosis & 3 & 33 & 155 & 291 \\
\hline BAYSSON[29] & France & 1990-99 & $C-C$ & Kodalpha LR115 & $\mathrm{M} / \mathrm{F}$ & Hospital & Diagnosis & 44 & 344 & 521 & 797 \\
\hline KReUzer[30] & $\begin{array}{l}\text { Germany: } \\
\text { eastern }\end{array}$ & $1991-97$ & $\mathrm{C}-\mathrm{C}$ & Alpha track & $\mathrm{M} / \mathrm{F}$ & General & Diagnosis & 96 & 544 & 850 & 994 \\
\hline KREIENBROCK[31] & $\begin{array}{l}\text { Germany: } \\
\text { western }\end{array}$ & $1990-95$ & $\mathrm{C}-\mathrm{C}$ & $\begin{array}{l}\text { Solid-state } \\
\text { nuclear track }\end{array}$ & $M / F$ & General & Diagnosis & 89 & 653 & 1225 & 1433 \\
\hline Восніссніо[32] & Italy & $1993-96$ & $\mathrm{C}-\mathrm{C}$ & $\begin{array}{l}\text { Radon } \\
\text { dosimeter }\end{array}$ & $\mathrm{M} / \mathrm{F}$ & Hospital & Diagnosis & 28 & 102 & 355 & 291 \\
\hline BARROS-DIOS [33] & Spain & $1992-94$ & $\mathrm{C}-\mathrm{C}$ & Alpha track & $\mathrm{M} / \mathrm{F}$ & General & Diagnosis & 12 & 94 & 144 & 133 \\
\hline Pershagen[34] & Sweden & $1980-84$ & $\mathrm{C}-\mathrm{C}$ & $\begin{array}{l}\text { Solid-state alpha } \\
\text { track }\end{array}$ & $\mathrm{M} / \mathrm{F}$ & General & Diagnosis & 175 & 1156 & 682 & 761 \\
\hline LAGARDE[35] & Sweden & $1978-95$ & $\mathrm{C}-\mathrm{C}$ & $\begin{array}{c}\text { Radon } \\
\text { dosimeter }\end{array}$ & $\mathrm{M} / \mathrm{F}$ & General & Diagnosis & 258 & 487 & & \\
\hline Pershagen[44] & $\begin{array}{l}\text { Sweden: } \\
\text { Stockholm }\end{array}$ & $1983-87$ & $\mathrm{C}-\mathrm{C}$ & Alpha track & $\mathrm{F}$ & General+hospital & Diagnosis & 36 & 181 & 160 & 194 \\
\hline$D_{A R B Y}[36]$ & England & $1988-95$ & $\mathrm{C}-\mathrm{C}$ & $\begin{array}{l}\text { Small passive } \\
\text { radon }\end{array}$ & $M / F$ & General+hospital & Diagnosis & 26 & 896 & 874 & 2062 \\
\hline 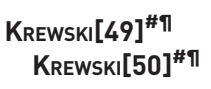 & North America & $1982-97$ & Pooled study & & $M / F$ & General & Diagnosis & 659 & 2185 & 2930 & 2681 \\
\hline SchoenBERG[37] & USA: New Jersey & $1982-84$ & $\mathrm{C}-\mathrm{C}$ & Alpha track & $\mathrm{F}$ & General & Diagnosis & 61 & 213 & 372 & 189 \\
\hline LETOURNEAU[38] & $\begin{array}{l}\text { Canada: } \\
\text { Winnipeg }\end{array}$ & $1983-90$ & $\mathrm{C}-\mathrm{C}$ & $\begin{array}{l}\text { CR-39 alpha } \\
\text { track }\end{array}$ & $\mathrm{M} / \mathrm{F}$ & General & Diagnosis & 24 & 224 & 509 & 498 \\
\hline Alavanja[39] & USA: Missouri & $1986-92$ & $\mathrm{C}-\mathrm{C}$ & Alpha track & $\mathrm{F}$ & General & Diagnosis & 377 & 983 & 161 & 200 \\
\hline Alavanja[45] & USA: Missouri & $1993-94$ & $\mathrm{C}-\mathrm{C}$ & $\begin{array}{c}\text { CR-39 } \\
\text { alpha-particle }\end{array}$ & $\mathrm{F}$ & General & Diagnosis & 31 & 62 & 471 & 480 \\
\hline FIELD $[40]$ & USA: Iowa & $1993-97$ & $\mathrm{C}-\mathrm{C}$ & Alpha track & $\mathrm{F}$ & General & Diagnosis & 56 & 414 & 357 & 200 \\
\hline SANDLER [65] & $\begin{array}{l}\text { USA: } \\
\text { Connecticut }\end{array}$ & $1989-92$ & $\mathrm{C}-\mathrm{C}$ & Alpha track etch & $\mathrm{M} / \mathrm{F}$ & General & Diagnosis & 54 & 78 & 718 & 735 \\
\hline SANDLER $[65]$ & USA: Utah & 1989-92 & $\mathrm{C}-\mathrm{C}$ & Alpha track etch & $\mathrm{M} / \mathrm{F}$ & General & Diagnosis & 56 & 211 & 342 & 379 \\
\hline
\end{tabular}




\begin{tabular}{|c|c|c|c|c|c|c|c|c|c|c|c|}
\hline \multirow{2}{*}{$\begin{array}{l}\text { First author } \\
\text { [ref.] }\end{array}$} & \multirow[t]{2}{*}{ Country/region } & \multirow[t]{2}{*}{ Study period } & \multirow[t]{2}{*}{ Study design } & \multirow{2}{*}{$\begin{array}{l}\text { Radon detection } \\
\text { technique }\end{array}$} & \multirow[t]{2}{*}{ Sex } & \multirow{2}{*}{$\begin{array}{l}\text { Population } \\
\text { source }\end{array}$} & \multirow{2}{*}{$\begin{array}{c}\text { Outcome: LC } \\
\text { diagnosis/ } \\
\text { death }\end{array}$} & \multicolumn{2}{|c|}{ Never-smokers } & \multicolumn{2}{|c|}{ Ever-smokers } \\
\hline & & & & & & & & Cases & Controls & Cases & Controls \\
\hline $\begin{array}{l}\text { LUBIN[46] }{ }^{\# \uparrow} \\
\quad \text { LUBIN[47] }\end{array}$ & China & $1985-98$ & Pooled study & & $M / F$ & General & Diagnosis & $322^{+}$ & $708^{+}$ & 706 & 1266 \\
\hline BLOT[42] & China: Shenyang & $1985-87$ & $C-C$ & $\begin{array}{l}\text { Radon } \\
\text { dosimeter }\end{array}$ & $\mathrm{F}$ & General & Diagnosis & 113 & 213 & 162 & 120 \\
\hline$W_{A N G}[43]$ & China: Gansu & 1994-98 & $\mathrm{C}-\mathrm{C}$ & Alpha track & $M / F$ & General & Diagnosis & 209 & 495 & 544 & 1146 \\
\hline $\begin{array}{l}\text { LORENZO-GoNZALEZ } \\
{[52]^{\# \S}}\end{array}$ & Spain: northwest & 2003-13 & Pooled study & Alpha track & $M / F$ & Hospital & Diagnosis & $476^{+}$ & $656^{+}$ & $261^{f}$ & $264^{f}$ \\
\hline $\begin{array}{l}\text { BARROS-DIOS } \\
{[66]^{T 1}}\end{array}$ & Spain: Galicia & 2004-08 & $\mathrm{C}-\mathrm{C}$ & Alpha track & $M / F$ & Hospital & Diagnosis & 47 & 220 & 261 & 264 \\
\hline $\begin{array}{l}\text { ToRres-DURAN } \\
{[64]^{\# \#}}\end{array}$ & Spain: Galicia & $2011-13$ & $\mathrm{C}-\mathrm{C}$ & Alpha track & $M / F$ & Hospital & Diagnosis & 192 & 329 & & \\
\hline 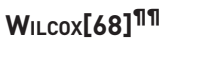 & $\begin{array}{l}\text { USA: New } \\
\text { Jersey }\end{array}$ & $1989-92$ & $\mathrm{C}-\mathrm{C}$ & Alpha track & $M / F$ & General & Diagnosis & 40 & 116 & 521 & 513 \\
\hline TuRneR[67] & USA & $1982-88$ & Cohort & $\begin{array}{c}\text { Mean } \\
\text { county-level of } \\
\text { radon }\end{array}$ & $M / F$ & General & Death & 271 & 375087 & 2733 & 355286 \\
\hline
\end{tabular}

Data are presented as n. LC: lung cancer; C-C: case-control study; M: male; F: female. ": these studies are included in the meta-analysis for never-smokers; ": these studies are included in the meta-analysis for ever-smokers; ${ }^{+}$: unpublished data provided by original investigators; ${ }^{\S}$ : this study has been revised by its lead investigator to exclude the results of

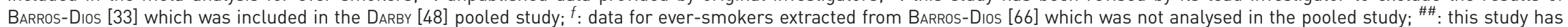
been updated from July 2013 by its lead investigator to include more cases and controls in the Lorenzo-GonzALEz [52] pooling study; ${ }^{\text {1ा: }}$ : these studies are not included in the meta-analysis due to different measures of effect (cohort study) or standard errors or confidence intervals (case-control study) not reported for their risk estimates. 


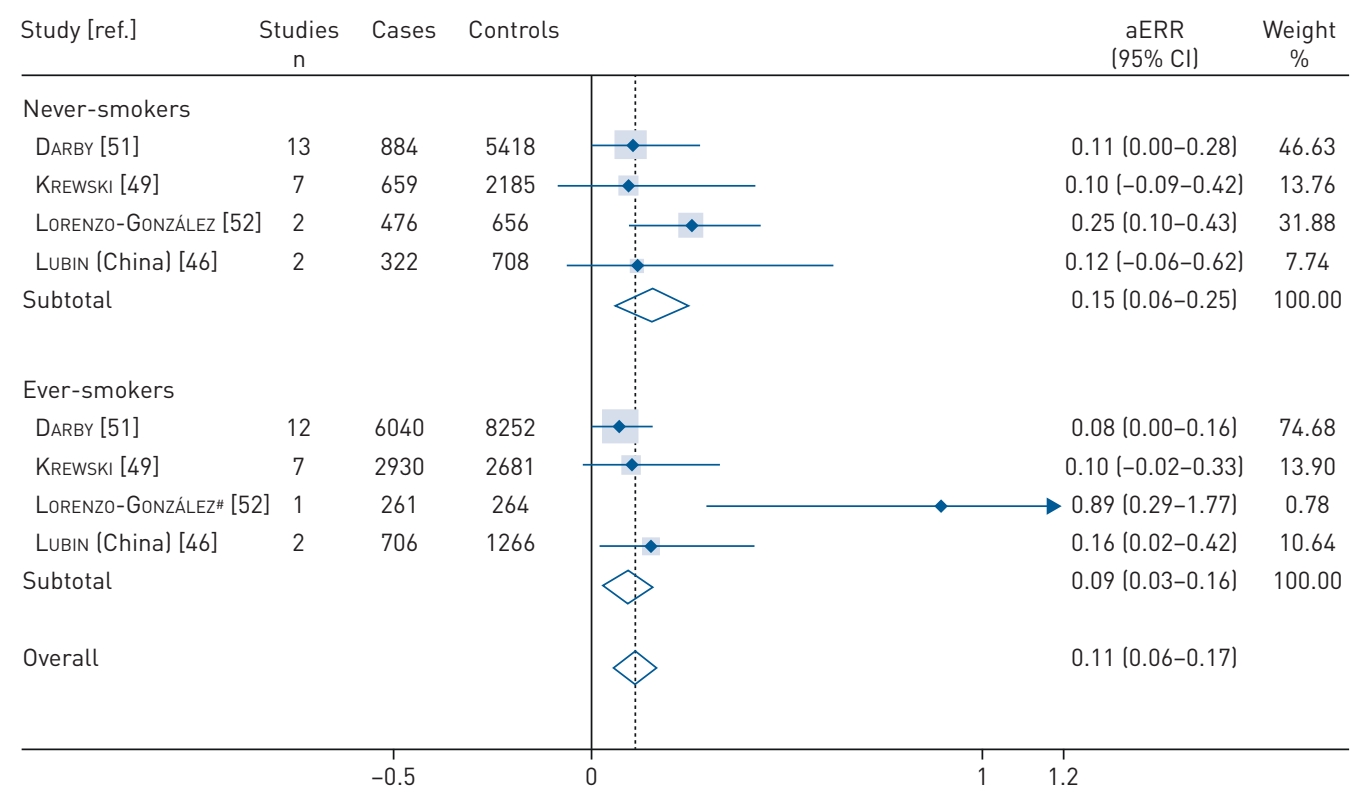

FIGURE 2 Adjusted excess relative risk (aERR) and $95 \% \mathrm{Cl}$ per $100 \mathrm{~Bq} \cdot \mathrm{m}^{-3}$ (radon exposure) for diagnosis of lung cancer. \#: BARRos-Dios et al. [66] in this pooled study contributed to the "ever-smoker" meta-analysis. $p=0.32$ for test of difference between aERRs for never-smokers and ever-smokers.

ever-smokers and 0.11 (95\% CI 0.06-0.17) overall (figure 2). The aERR for never-smokers was not significantly different from that for ever-smokers $(\mathrm{p}=0.32)$. Sensitivity analyses which combined component effect estimates on the $\log (\mathrm{RR})$ scale using the standard generic inverse variance method provided similar pooled effect estimates (but on the RR scale) (supplementary figure 1) and a similar $\mathrm{p}$-value for the difference between aRRs for never-smokers and ever-smokers $(\mathrm{p}=0.35)$.

We also found different effects of radon on lung cancer risk for never-smokers by sex: aERRs per $100 \mathrm{~Bq} \cdot \mathrm{m}^{-3}$ were 0.09 (95\% CI -0.02-0.20) for women and 0.46 (95\% CI 0.15-0.76) for men; and the difference between them was significant $(\mathrm{p}=0.027)$ (figure 3$)$. The results from the sensitivity analysis were similar (supplementary figure 2).

For risk of death from lung cancer for never-smokers, TURNER et al. [67] reported an adjusted HR of 0.77 (95\% CI $0.47-1.25)$ per $100 \mathrm{~Bq} \cdot \mathrm{m}^{-3}$ in mean county-level residential radon concentrations during a 6 year follow-up.

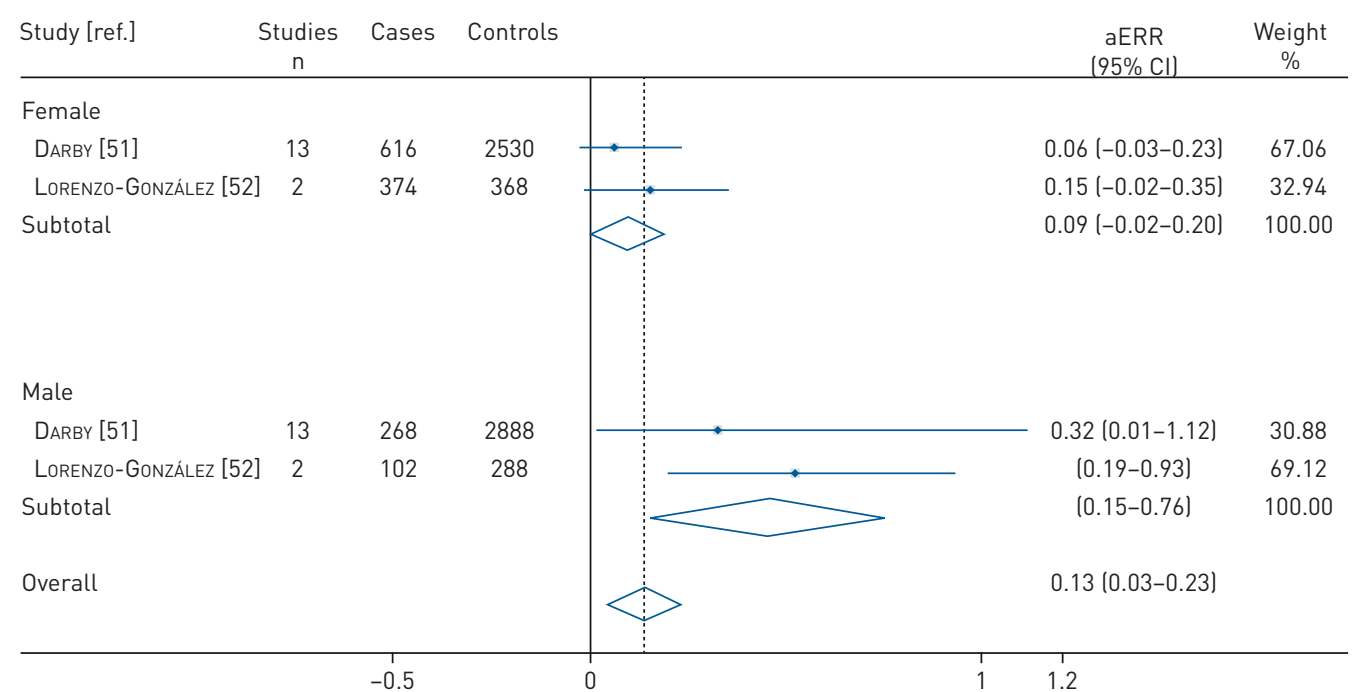

FIGURE 3 Adjusted excess relative risk (aERR) and $95 \% \mathrm{Cl}$ per100 Bq. $\mathrm{m}^{-3}$ (radon exposure) for diagnosis of lung cancer in never-smokers stratified by sex. $p=0.027$ for difference between male and female aERRs. 


\section{Discussion}

This is the first systematic review and meta-analysis to quantify the association between residential radon exposure and lung cancer risk for lifelong never-smokers. As the population of never-smokers is increasing due to effective tobacco control policies in most countries, the link between radon and LCINS clearly has important implications, and our study was able to quantify this link. We found a $15 \%$ excess relative risk of lung cancer for never-smokers when exposed to radon levels per $100 \mathrm{~Bq} \cdot \mathrm{m}^{-3}$. The excess risk of lung cancer for ever-smokers was $9 \%$ per $100 \mathrm{~Bq} \cdot \mathrm{m}^{-3}$ radon exposure and this was not statistically significantly different to that for never-smokers. The excess relative risks were $46 \%$ for men and $9 \%$ for women among never-smokers, and the difference between them was significant $(\mathrm{p}=0.027)$.

When examining the association between radon exposure and lung cancer risk, population studies conducted exclusively on never-smokers are recommended to reduce the potential residual confounding effects of smoking, as the impact of smoking on lung cancer risk is far stronger than that from residential radon at low exposure levels [69]. Nevertheless, despite radon being the most important risk factor for LCINS, we could only include 2341 never-smoker lung cancer cases (in contrast to 9937 ever-smoker cases) in this meta-analysis, highlighting the fact there is relatively little research carried out on this subgroup of patients with lung cancer. This could be explained by: 1) LCINS being a relatively rare disease compared with lung cancer in ever-smokers; and 2) general population statistics such as cancer registries and death certificates mostly lack information on lifetime smoking histories, which makes it difficult to identify eligible cases from population data.

By adhering to the methods specified in the PRISMA checklist, this study provided an objective assessment of the risk of residential radon on lung cancer for never-smokers. To ensure that individual studies were included only once for analysis, the pooled collaborative studies were prioritised given the increased study power, which potentially allows both evaluation of effect modification [70] and more reliable results [71]. As a result, four pooled collaborative studies which reported 24 case-control studies and two individual studies (one case-control and one cohort) were included in the systematic review, and among these studies, data from the four pooled collaborative studies were extracted for inclusion in the meta-analysis. This provided the largest sample size to date for assessing the lung cancer risk of residential radon exposure among never-smokers. All case-control studies in the included pooled collaborative studies were adjusted for confounders, and this is also a strength of our results. In addition, our study provides the estimated excess relative risk for ever-smokers and allows a comparison with that for never-smokers, thereby evaluating a possible role of smoking as an effect modifier.

Of the four pooled studies, the greatest effect size (aERR 0.25) was observed in the Spanish pooled study [52]. A possible explanation for this result is that the Spanish studies were conducted in more radon-prone areas than the other pooled studies. Specifically, the Spanish study pooled four individual studies conducted in northwest Spain (including Galicia) where radon is emitted at relatively high levels due to the granitic nature of their soils [33], with about $25 \%$ of all homes in the area registering radon concentrations $\geqslant 148 \mathrm{~Bq} \cdot \mathrm{m}^{-3}$. When compared with a more recent pooled case-control study assessing the relationship between residential radon exposure and lung cancer risk in the same regions and performed by the same group [72], both results did not differ appreciably from each other, suggesting that in a given radon-prone area, results on indoor radon and lung cancer risk would be consistent. Meanwhile, in the North American pooled study [49] the highest radon concentrations $\left(>7201 \mathrm{~Bq} \cdot \mathrm{m}^{-3}\right)$ were detected in Winnipeg [38, 49], but no increased risk of residential radon for LCINS was observed. Also, in the Missouri-II study [45] where radon concentrations were higher than $148 \mathrm{~Bq} \cdot \mathrm{m}^{-3}$, contrasting results (with and without statistically significant findings) were observed depending on the method of radon exposure measurement [73]. Therefore, while radon-prone areas serve as one of the major factors in determining the results, other factors like uncertainties of indoor radon exposure assessment and uncertainty of equilibrium factor $\mathrm{F}$ due to geographical variations might also play an important role [24, 74]. The effects of these uncertainties have been evaluated and it was shown that the errors could have led to an underestimation of the reported ERR values [74]. Nevertheless, during the long study period (1960-2013) of this meta-analysis, methods on radon detection and lung cancer diagnosis remain fairly consistent and there is no evidence to suggest any significant discrepancy across this long study period $[75,76]$.

Previous studies have not established whether the effect of radon on lung cancer risk is different between men and women. Studies based on both ever-smokers and never-smokers have produced inconsistent results $[47,49,51,54]$. Due to the overwhelming confounding effect of smoking, the effect of radon for men and women separately should be assessed among never-smokers. As most never-smokers are predominantly women and over $75 \%$ of the LCINS cases in our selected studies were women, there was less precision in the estimates of risk from residential radon for male never-smokers. Also, while the occupational miners' studies included relatively large populations of men, the effects of radon exposure within miners is not comparable to the effects of residential radon exposure in the general population. 
Despite these limitations, we found that the excess relative risk of LCINS in relation to residential radon exposure was greater for men than women. As there is no strong evidence to suggest different susceptibility to lung carcinogens by sex [17], further work is needed to elucidate potential differences between male and female never-smokers, and whether they can be explained by other factors.

Historically, owing to the relatively high radon concentrations in underground mines, epidemiological studies of occupational miners constituted an important and practical resource for research on radon-induced lung cancer. The US National Research Council's sixth committee on the Biological Effect of Ionising Radiation (BEIR-VI) developed exposure-response risk models based on the analysis of data from studies of occupational miners to estimate lung cancer risk associated with residential radon exposure and to project the risk for individuals as well as for the entire US population [17]. To extend the risk models from occupational miners to the general population, the committee adopted a set of assumptions including a linear-non-threshold relationship between radon exposure and lung cancer risk for the relatively low levels of residential radon exposures. Despite some initial controversies, the models are generally accepted after their validation with case-control studies conducted at the population level [46, $48,49]$. It is also worth noting that miners with low radon exposure could experience similar radon exposure to long-term residents with cumulative exposure to high radon concentrations in domestic dwellings. Consequently, the downward extrapolation for lung cancer risks from occupationally exposed miners to residentially exposed inhabitants conformed very closely to the observed aERRs from residential radon studies. This was demonstrated in our results as our overall aERR of 0.11 (95\% CI 0.06-0.17) per $100 \mathrm{~Bq} \cdot \mathrm{m}^{-3}$ was compatible with the excess odds ratio of $0.12(95 \% \mathrm{CI} 0.02-0.25)$ per $100 \mathrm{~Bq} \cdot \mathrm{m}^{-3}$ as predicted by extrapolation from miner studies in the BEIR-VI report [17].

To assess the risk of radon exposure for the general population which includes both never- and ever-smokers, it is important to understand the joint effects of tobacco smoke and radon because of the overwhelming role of smoking as a causal factor for lung cancer. If the joint effects of smoking and radon exposure are additive, then the absolute increase in lung cancer risk attributable to radon exposure is the same in ever-smokers and never-smokers, and therefore proportionally less in ever-smokers, given they have a much higher lung cancer risk than never-smokers. Whereas if the joint effects are multiplicative, then the absolute increase in the lung cancer risk attributable to radon exposure is substantially greater for smokers, and therefore the relative risks for radon exposure are the same in ever-smokers and never-smokers [77]. Since there is evidence for a synergistic relationship between radon and smoking, it implies "greater than additive" joint effects and is either a multiplicative joint association or "sub-multiplicative" association (i.e. intermediate between additive and multiplicative) [17]. The BEIR-VI committee applied both a full and a sub-multiplicative model, and it was found that a sub-multiplicative model was more consistent with the available data. Our finding that the excess relative risks of radon were greater in never-smokers than that in ever-smokers but not significantly different $(p=0.32)$, implies there was also consistency with a sub-multiplicative association, which is in line with the BEIR-VI report [17].

Despite evidence from cellular, molecular, epidemiological and animal studies providing some understanding of the biological mechanisms involved in radon-induced lung cancer, the mechanism is still not fully known. Radiation carcinogenesis is a complicated process and subject to the effects of different environmental agents and genetic factors [78]. The carcinogenic effect induced by inhaled radon, particularly to the bronchial epithelium and at bifurcation sites, is mainly through radon progenies, mostly polonium 214 and 218, which emit high energy alpha particles as the predominant form of radiation [17]. Despite their limited capacity in tissue penetration, alpha particles can induce significant biological damage in exposed tissues (due to their high relative biological effectiveness) through a variety of cytogenetic effects. Some of these effects include gene mutations, chromosome aberrations, generation of reactive oxygen species, modified cell cycles and increased production of proteins associated with cell-cycle regulation and carcinogenesis [79]. There is also evidence suggesting that residential radon exposure could play a role in the expression of epidermal growth factor receptor (EGFR) mutations and anaplastic lymphoma kinase (ALK) translocations [80], and appears to increase the risk of small cell lung cancer among all histological types [66, 81].

This study has several limitations. First, this systematic review is limited by exclusion of the grey literature and conference proceedings, and thus the review may not contain all relevant articles. Also, though requiring included studies to be published in peer reviewed journals provides a useful level of quality control, it may potentially lead to publication bias. Nevertheless, we covered more publications than the other similar systematic reviews on this topic and included a great number of LCINS cases from studies conducted in different regions of the world and by different researchers, and this has reduced the publication bias to a minimum degree. Secondly, despite efforts from the study investigators to standardise exposure assessment, there remained potential measurement bias introduced by random uncertainties due to the inaccuracy and discrepancy of the assessment of individual residential radon concentrations across 
the individual studies. Thirdly, because measures of heterogeneity for relevant effect estimates were not reported in the pooled collaborative studies, we were unable to assess heterogeneity or examine potential sources of heterogeneity in our meta-analysis.

These limitations notwithstanding, this meta-analysis has several strengths. First, this is the first meta-analysis to provide a quantified risk estimate (aERR of 0.15 per $100 \mathrm{~Bq} \cdot \mathrm{m}^{-3}$ radon level) for the association of residential radon exposure with lung cancer among never-smokers. Secondly, it includes the most up-to-date data with the largest numbers of cases and controls from studies conducted in many parts of the world (including both radon-prone and low-radon areas). Thirdly, the results conform well to the risk assessment of radon exposure from BEIR-VI by extrapolating lung cancer risks from occupationally exposed miners to residentially exposed inhabitants. Also, our results are in line with the BEIR-VI report suggesting a sub-multiplicative model for the joint effects of radon exposure and tobacco smoke. In addition, with the low ROB in the included studies, the precision of the point estimates of the effects of radon and the consistency of the study results, there are good grounds for believing that the body of evidence is in good strength.

This meta-analysis not only confirms the association between residential radon concentration and lung cancer risk, but also quantifies the risk estimates for the association among never-smokers and ever-smokers per $100 \mathrm{~Bq} \cdot \mathrm{m}^{-3}$ of radon exposure. Since the relative increase in risk for never-smokers is not significantly different from the corresponding relative increase in risk for ever-smokers, it also provides evidence for a synergistic interaction between radon and smoking. From a clinical perspective, when never-smokers are diagnosed with lung cancer, radon should be considered as a potential cause, especially in high-radon areas [82]. From a public health perspective, residential radon should be considered as an important factor for predicting lung cancer risk in radon-prone areas [83], especially among ever-smokers due to radon's synergistic effect with tobacco smoke, and smoking cessation should be among their top health priorities. Our findings also quantify the ERRs for never-smokers and ever-smokers at the World Health Organization's "action level of radon" of $100 \mathrm{~Bq} \cdot \mathrm{m}^{-3}$ [18] (environments and structures measuring higher than the "action level" are advised to take remedial "action" to lower radon levels). This level should be recommended rather than the level at $148 \mathrm{~Bq} \cdot \mathrm{m}^{-3}$ set by the United States Environmental Protection Agency [19], or even the EU action level of $300 \mathrm{~Bq} \cdot \mathrm{m}^{-3}$ [84, 85]. In fact, among 157400 of lung cancer deaths (for both ever-smokers and never-smokers) in the USA in 1995, at least 15400 were attributable to radon [17]. Hence, it may be important to set a lower action level (from 148 to $100 \mathrm{~Bq} \cdot \mathrm{m}^{-3}$ ) as one part of an overall strategy to reduce the mortality rate. Nevertheless, for high-radon areas, prompt remedial action should be taken to reduce further exposure to residents.

In conclusion, our meta-analysis demonstrated a significant association of residential radon exposure with lung cancer as observed in never-smokers and ever-smokers with aERRs of 0.15 and 0.09 per $100 \mathrm{~Bq} \cdot \mathrm{m}^{-3}$ respectively, and there was evidence to support a synergistic effect of radon exposure with tobacco smoking. Furthermore, lung cancer risk associated with residential radon may be greater for men than women never-smokers, although the potential mechanisms underlying differences in risk by sex remain

TABLE 3 Important findings and impact on public health

$\begin{array}{lc}\text { Important findings } & \text { Impact on public health } \\ \begin{array}{l}\text { This is the first systematic review and meta-analysis } \\ \text { which provides quantified risk estimates for lung } \\ \text { cancer from residential radon exposure, with } \\ \text { aERRs of } 0.15 \text { and } 0.09 \text { per } 100 \mathrm{~Bq} \cdot \mathrm{m}^{-3} \text { among } \\ \text { never-smokers and ever-smokers respectively }\end{array} & \begin{array}{c}\text { These findings quantify the excess relative risks for } \\ \text { never-smokers and ever-smokers at the WHO } \\ \text { "action level of radon" of } 100 \mathrm{~Bq} \cdot \mathrm{m}^{-3}\end{array} \\ \begin{array}{l}\text { There was evidence to support a synergistic } \\ \text { interaction between radon and tobacco smoking }\end{array} & \begin{array}{c}\text { Ever-smokers living in radon-prone areas should } \\ \text { be considered as a high-risk group and smoking } \\ \text { cessation should be among their top health } \\ \text { priorities }\end{array} \\ \begin{array}{c}\text { Among never-smokers, aERR of lung cancer per } \\ \begin{array}{l}100 \mathrm{~Bq} \cdot \mathrm{m}^{-3} \text { of radon exposure was higher for men } \\ \text { than women }\end{array}\end{array} & \begin{array}{c}\text { Among never-smokers in radon-prone areas, men } \\ \text { may need to take greater caution than women to } \\ \text { avoid or reduce their exposure to radon }\end{array}\end{array}$

aERR: adjusted excess relative risk; WHO: World Health Organization. 
unknown and represent a key area of future research. The public health impact of these findings is summarised in table 3.

Author contributions: E.S. Cheng conceived the study. Systematic review: P. Rawstorne, S. Hughes and X.Q. Yu designed and supervised the conduct of it, E.S. Cheng searched and extracted the data, and S. Hughes and X.Q. Yu evaluated the study selection. Meta-analysis: E.S. Cheng and S. Egger extracted the study estimates, A. Ruano-Ravina supplied some unpublished analysed data, S. Egger performed the analysis, S. Egger, X.Q. Yu and E.S. Cheng evaluated the results, and A. Ruano-Ravina contributed to the interpretation of the results. E.S. Cheng drafted the manuscript, and all authors reviewed, revised and approved the final manuscript.

Conflict of interest: E.S. Cheng has no conflicts of interest to declare. S. Egger has nothing to disclose. S. Hughes has nothing to disclose. M. Weber reports other support from Cancer Australia and Australian Department of Health, outside the submitted work. J. Steinberg has nothing to disclose. B. Rahman has nothing to disclose. H. Worth has nothing to disclose. A. Ruano-Ravina has nothing to disclose. P. Rawstorne has nothing to disclose. X.Q. Yu has nothing to disclose.

Support statement: This work was supported by the Cancer Council NSW (PhD Scholarship program). Funding information for this article has been deposited with the Crossref Funder Registry.

\section{References}

1 Ferlay J, Colombet M, Soerjomataram I, et al. Estimating the global cancer incidence and mortality in 2018: GLOBOCAN sources and methods. Int J Cancer 2019; 144: 1941-1953.

2 Sun S, Schiller JH, Gazdar AF. Lung cancer in never smokers - a different disease. Nat Rev Cancer 2007; 7: 778-790.

3 Torok S, Hegedus B, Laszlo V, et al. Lung cancer in never smokers. Future Oncol 2011; 7: 1195-1211.

4 Mak KS, van Bommel AC, Stowell C, et al. Defining a standard set of patient-centred outcomes for lung cancer. Eur Respir J 2016; 48: 852-860.

5 Toh C-K, Gao F, Lim W-T, et al. Never-smokers with lung cancer: epidemiologic evidence of a distinct disease entity. J Clin Oncol 2006; 24: 2245-2251.

6 Subramanian J, Govindan R. Lung cancer in 'Never-smokers': a unique entity. Oncology (Williston Park) 2010; 24: 29-35.

7 Couraud S, Zalcman G, Milleron B, et al. Lung cancer in never smokers - a review. Eur J Cancer 2012; 48: 1299-1311.

8 Dias M, Linhas R, Campainha S, et al. Lung cancer in never-smokers - what are the differences? Acta Oncol 2017; 56: 931-935.

9 Parkin DM, Bray F, Ferlay J, et al. Global cancer statistics, 2002. CA Cancer J Clin 2005; 55: 74-108.

10 Thun MJ, Henley SJ, Burns D, et al. Lung cancer death rates in lifelong nonsmokers. J Natl Cancer Inst 2006; 98: 691-699.

11 Clement-Duchene C, Vignaud JM, Stoufflet A, et al. Characteristics of never smoker lung cancer including environmental and occupational risk factors. Lung Cancer 2010; 67: 144-150.

12 Torres-Duran M, Ruano-Ravina A, Parente-Lamelas I, et al. Residential radon and lung cancer characteristics in never smokers. Int J Radiat Biol 2015; 91: 605-610.

13 Corrales L, Rosell R, Cardona AF, et al. Lung cancer in never smokers: the role of different risk factors other than tobacco smoking. Crit Rev Oncol Hematol 2020; 148: 102895.

14 International Agency for Research on Cancer. IARC monographs on the evaluation of carcinogenic risks to humans: man-made mineral fibres and radon. IARC 1988; 43: 1-300. https://monographs.iarc.fr/wp-content/ uploads/2018/06/mono43.pdf Date last accessed: 10 November 2019.

15 Lubin JH. Radon and Lung Cancer Risk: A Joint Analysis of 11 Underground Miners Studies. Bethesda, MD, US Dept. of Health and Human Services, Public Health Service, National Institutes of Health, 1994.

16 Oh SS, Koh S, Kang $\mathrm{H}$, et al. Radon exposure and lung cancer: risk in nonsmokers among cohort studies. Ann Occup Environ Med 2016; 28: 11.

17 National Research Council, Committee on Health Risks of Exposure to Radon, Board on Radiation Effects Research and Commission on Life Sciences. Health effects of exposure to radon: BEIR-VI. Washington, D.C., National Academy Press, 1999.

18 World Health Organization. WHO Handbook on Indoor Radon: A Public Health Perspective. Geneva, WHO, 2009.

19 US Environmental Protection Agency. A Citizen's Guide to Radon: The Guide to Protecting Yourself and Your Family from Radon. Washington, D.C., US Environmental Protection Agency, 2012. www.epa.gov/sites/ production/files/2016-02/documents/2012_a_citizens_guide_to_radon.pdf Date last accessed: 18 November 2019.

20 Hopke PK, Jensen B, Li CS, et al. Assessment of the exposure to and dose from radon decay products in normally occupied homes. Environ Sci Technol 1995; 29: 1359-1364.

21 Bagher AM, Vahid M, Mohsen M. Introduction to radioactive materials. J Renew Sust Energ 2014; 3: 59-67.

22 Janik M, Tokonami S, Kranrod C, et al. Comparative analysis of radon, thoron and thoron progeny concentration measurements. J Radiat Res 2013; 54: 597-610.

23 Darby S, Hill D, Doll R. Radon: a likely carcinogen at all exposures. Ann Oncol 2001; 12: 1341-1351.

24 Bochicchio F. Case-control studies on residential radon and lung cancer: a concise review. Arch Oncol 2004; 12: $19-24$.

25 Oberaigner W, Kreienbrock L, Schaffrath Rosario A, et al. Radon und Lungenkrebs im Bezirk Imst/Österreich. Fortschritte in der Umweltmedizin. Landsberg am Lech, Ecomed Verlagsgesellschaft, 2002.

26 Tomasek L, Muller T, Kunz E, et al. Study of lung cancer and residential radon in the Czech Republic. Cent Eur J Public Health 2001; 9: 150-153.

27 Auvinen A, Makelainen I, Hakama M, et al. Indoor radon exposure and risk of lung cancer: a nested case-control study in Finland. J Natl Cancer Inst 1996; 88: 966-972. 
30 Kreuzer Epidemiology 2003; 14: 559-568

31 Kreienbrock L, Kreuzer M, Gerken M, et al. Case-control study on lung cancer and residential radon in western Germany. Am J Epidemiol 2001; 153: 42-52.

32 Bochicchio F, Forastiere F, Farchi S, et al. Residential radon exposure, diet and lung cancer: a case-control study in a Mediterranean region. Int J Cancer 2005; 114: 983-991.

33 Barros-Dios JM, Barreiro MA, Ruano-Ravina A, et al. Exposure to residential radon and lung cancer in Spain: a population-based case-control study. Am J Epidemiol 2002; 156: 548-555.

34 Pershagen G, Akerblom G, Axelson O, et al. Residential radon exposure and lung cancer in Sweden. $N$ Engl J Med 1994; 330: 159-164.

35 Lagarde F, Axelsson G, Damber L, et al. Residential radon and lung cancer among never-smokers in Sweden. Epidemiology 2001; 12: 396-404.

36 Darby S, Whitley E, Silcocks $\mathrm{P}$, et al. Risk of lung cancer associated with residential radon exposure in south-west England: a case-control study. Br J Cancer 1998; 78: 394-408.

37 Schoenberg JB, Klotz JB, Wilcox HB, et al. Case-control study of residential radon and lung cancer among New Jersey women. Cancer Res 1990; 50: 6520-6524.

38 Letourneau EG, Krewski D, Choi NW, et al. Case-control study of residential radon and lung cancer in Winnipeg, Manitoba, Canada. Am J Epidemiol 1994; 140: 310-339.

39 Alavanja MC, Brownson RC, Lubin JH, et al. Residential radon exposure and lung cancer among nonsmoking women. J Natl Cancer Inst 1994; 86: 1829-1837.

40 Field RW, Steck DJ, Smith BJ, et al. Residential radon gas exposure and lung cancer: the Iowa Radon Lung Cancer Study. Am J Epidemiol 2000; 151: 1091-1102.

41 Sandler DP. Indoor radon and lung cancer risk: a case-control study in Connecticut and Utah. Radiat Res 1999; 151: $103-104$.

42 Blot WJ, Xu ZY, Boice JD Jr, et al. Indoor radon and lung cancer in China. J Natl Cancer Inst 1990; 82: $1025-1030$

43 Wang Z, Lubin JH, Wang L, et al. Residential radon and lung cancer risk in a high-exposure area of Gansu Province, China. Am J Epidemiol 2002; 155: 554-564.

44 Pershagen G, Liang ZH, Hrubec Z, et al. Residential radon exposure and lung cancer in Swedish women. Health Phys 1992; 63: 179-186.

45 Alavanja MC, Lubin JH, Mahaffey JA, et al. Residential radon exposure and risk of lung cancer in Missouri. Am J Public Health 1999; 89: 1042-1048.

46 Lubin JH. Studies of radon and lung cancer in North America and China. Radiat Prot Dosimetry 2003; 104: 315-319.

47 Lubin JH, Wang ZY, Boice JD, Jr., et al. Risk of lung cancer and residential radon in China: pooled results of two studies. Int J Cancer 2004; 109: 132-137.

48 Darby S, Hill D, Auvinen A, et al. Radon in homes and risk of lung cancer: collaborative analysis of individual data from 13 European case-control studies. BMJ 2005; 330: 223.

49 Krewski D, Lubin JH, Zielinski JM, et al. Residential radon and risk of lung cancer: a combined analysis of 7 North American case-control studies. Epidemiology 2005; 16: 137-145.

50 Krewski D, Lubin JH, Zielinski JM, et al. A combined analysis of north American case-control studies of residential radon and lung cancer. J Toxicol Environ Health A 2006; 69: 533-597.

51 Darby S, Hill D, Deo H, et al. Residential radon and lung cancer - detailed results of a collaborative analysis of individual data on 7148 persons with lung cancer and 14,208 persons without lung cancer from 13 epidemiologic studies in Europe. Scand J Work Environ Health 2006; 32: Suppl. 1, 1-83.

52 Lorenzo-Gonzalez M, Ruano-Ravina A, Torres-Duran M, et al. Lung cancer and residential radon in never-smokers: a pooling study in the Northwest of Spain. Environ Res 2019; 172: 713-718.

53 Lubin JH, Boice JD, Jr. Lung cancer risk from residential radon: meta-analysis of eight epidemiologic studies. J Natl Cancer Inst 1997; 89: 49-57.

54 Pavia M, Bianco A, Pileggi C, et al. Meta-analysis of residential exposure to radon gas and lung cancer. Bull World Health Organ 2003; 81: 732-738.

55 Garzillo C, Pugliese M, Loffredo F, et al. Indoor radon exposure and lung cancer risk: a meta-analysis of case-control studies. Transl Cancer Res 2017; 6: S934-S943.

56 Dobrzynski L, Fornalski KW, Reszczynska J. Meta-analysis of thirty-two case-control and two ecological radon studies of lung cancer. J Radiat Res 2018; 59: 149-163.

57 Malinovsky G, Yarmoshenko I, Vasilyev A. Meta-analysis of case-control studies on the relationship between lung cancer and indoor radon exposure. Radiat Environ Biophys 2019; 58: 39-47.

58 Li C, Wang C, Yu J, et al. Residential radon and histological types of lung cancer: a meta-analysis of case-control studies. Int J Environ Res Public Health 2020; 17: 1457.

59 Lubin JH, Samet JM, Weinberg C. Design issues in epidemiologic studies of indoor exposure to Rn and risk of lung cancer. Health Phys 1990; 59: 807-817.

60 Moher D, Shamseer L, Clarke M, et al. Preferred reporting items for systematic review and meta-analysis protocols (PRISMA-P) 2015 statement. Syst Rev 2015; 4: 1.

61 Whiting P, Savovic J, Higgins JP, et al. ROBIS: a new tool to assess risk of bias in systematic reviews was developed. J Clin Epidemiol 2016; 69: 225-234.

62 Kirk M, Smurthwaite K, Bräunig J, et al. The PFAS Health Study: Systematic Literature Review. Canberra, The Australian National University, 2018.

63 Little MP, Azizova TV, Bazyka D, et al. Systematic review and meta-analysis of circulatory disease from exposure to low-level ionizing radiation and estimates of potential population mortality risks. Environ Health Perspect 2012; 120: 1503-1511. 
64 Torres-Duran M, Ruano-Ravina A, Parente-Lamelas I, et al. Lung cancer in never-smokers: a case-control study in a radon-prone area (Galicia, Spain). Eur Respir J 2014; 44: 994-1001.

65 Sandler DP, Weinberg CR, Shore DL, et al. Indoor radon and lung cancer risk in connecticut and utah. J Toxicol Environ Health A 2006; 69: 633-654.

66 Barros-Dios JM, Ruano-Ravina A, Perez-Rios M, et al. Residential radon exposure, histologic types, and lung cancer risk. A case-control study in Galicia, Spain. Cancer Epidemiol Biomarkers Prev 2012; 21: 951-958.

67 Turner MC, Krewski D, Chen Y, et al. Radon and lung cancer in the American Cancer Society cohort. Cancer Epidemiol Biomarkers Prev 2011; 20: 438-448.

68 Wilcox HB, Al-Zoughool M, Garner MJ, et al. Case-control study of radon and lung cancer in New Jersey. Radiat Prot Dosimetry 2008; 128: 169-179.

69 Conrady J, Martin K, Lembcke J, et al. The true size of the lung cancer risk from indoor radon: hidden behind a smoke screen? Int Congr 2002; 1225: 253-258.

70 Friedenreich CM. Commentary: improving pooled analyses in epidemiology. Int J Epidemiol 2002; 31: 86-87.

71 Blettner M, Sauerbrei W, Schlehofer B, et al. Traditional reviews, meta-analyses and pooled analyses in epidemiology. Int J Epidemiol 1999; 28: 1-9.

72 Lorenzo-Gonzalez M, Ruano-Ravina A, Torres-Duran M, et al. Lung cancer risk and residential radon exposure: a pooling of case-control studies in northwestern Spain. Environ Res 2020; 189: 109968.

73 Field RW, Krewski D, Lubin JH, et al. An overview of the North American residential radon and lung cancer case-control studies. J Toxicol Environ Health A 2006; 69: 599-631.

74 Onishchenko A, Zhukovsky M. The influence of uncertainties of radon exposure on the results of case-control epidemiological study. Int J Radiat Biol 2019; 95: 354-359.

75 Zhukovsky M, Onischenko A, Bastrikov V. Radon measurements - discussion of error estimates for selected methods. Appl Radiat Isot 2010; 68: 816-820.

76 Zhukovsky M, Onishchenko A, Varaksin A, et al. The influence of radon measurement errors on the uncertainties of epidemiological case-control studies. Radiat Prot Dosimetry 2011; 145: 243-247.

77 Lubin JH, Boice JD, Jr., Edling C, et al. Lung cancer in radon-exposed miners and estimation of risk from indoor exposure. J Natl Cancer Inst 1995; 87: 817-827.

78 Raabe OG. Ionizing radiation carcinogenesis. In: Nenoi M, ed. Current Topics in Ionizing Radiation Research Chapter 15. Rijeka, Croatia, InTech, 2012; pp. 299-348.

79 Robertson A, Allen J, Laney R, et al. The cellular and molecular carcinogenic effects of radon exposure: a review. Int J Mol Sci 2013; 14: 14024-14063.

80 Ruano-Ravina A, Torres-Duran M, Kelsey KT, et al. Residential radon, EGFR mutations and ALK alterations in never-smoking lung cancer cases. Eur Respir J 2016; 48: 1462-1470.

81 Rodriguez-Martinez A, Torres-Duran M, Barros-Dios JM, et al. Residential radon and small cell lung cancer. A systematic review. Cancer Lett 2018; 426: 57-62.

82 Ruano-Ravina A, Fernández-Villar A, Barros-Dios JM. Residential radon and risk of lung cancer in never-smokers. Arch Bronconeumol 2017; 53: 475-476.

83 Torres-Duran M, Fernandez-Villar A, Barros-Dios JM, et al. Residential radon: the neglected risk factor in lung cancer risk scores. J Thorac Oncol 2016; 11: 1384-1386.

84 European Commission Basic safety standards for protection against the dangers arising from exposure to ionising radiation. Council Directive 2013/59/EURATOM. Official Journal of the European Union 2014; 17 January.

85 Ruano-Ravina A, Kelsey KT, Fernandez-Villar A, et al. Action levels for indoor radon: different risks for the same lung carcinogen? Eur Respir J 2017; 50: 1701609. 